\title{
Characterization of Anaerovibrio burkinabensis sp. nov., a Lactate- Fermenting Bacterium Isolated from Rice Field Soils
}

\author{
ABOUBAKAR S. OUATTARA, ${ }^{1}$ ALFRED S. TRAORE, ${ }^{2}$ AND JEAN-LOUIS GARCIA ${ }^{1 *}$ \\ Laboratoire de Microbiologie ORSTOM, Université de Provence, 3 Place Victor Hugo, 13331 Marseille Cédex 3, \\ France, ${ }^{1}$ and Département de Biochimie-Microbiologie I.S.N., Université de Ouagadougou, \\ Ouagadougou, Burkina Faso ${ }^{2}$
}

\begin{abstract}
A strictly anaerobic, gram-negative bacterium was isolated from rice field soils by using lactate as a sole carbon and energy source. The cells were non-spore-forming, motile, curved rods. Optimal growth occurred at $35^{\circ} \mathrm{C}$ and $\mathrm{pH} \mathrm{6.8}$. No $\mathrm{NaCl}$ requirement was observed. Vitamins were required for growth. Our isolate, strain $\mathbf{B}_{\mathbf{4}} \mathbf{B}_{\mathbf{0}}{ }^{T}(T=$ type strain), fermented pyruvate, fumarate, malate, citrate, dihydroxyacetone, fructose, 1,2-propanediol, glutamate, and aspartate to acetate, propionate, succinate, and traces of hydrogen. Strain $\mathbf{B}_{4} \mathbf{B}_{\mathbf{0}}{ }^{\mathrm{T}}$ did not use ribose or glycerol as an energy source, although glycerol degradation produced mainly 1,3-propanediol. Ferric iron was facultatively reduced. Nitrate and sulfate were not reduced. Cytochrome $b$ was present. The guanine-plus-cytosine content of the DNA was $44.1 \pm 0.1 \mathrm{~mol} \%$. We propose that strain $B_{4} B_{0}$ (= DSM 6283) should be the type strain of a new species in the genus Anaerovibrio, Anaerovibrio burkinabensis.
\end{abstract}

In wetland ecosystems, such as rice fields, the anaerobic mineralization of organic matter is a key mechanism in nutrient recycling, which involves several bacterial groups. Lactate is thought to be an important intermediary in this process since this compound is produced both from fermentation processes and as a rice root exudate. Lactate is consumed anaerobically by members of morphologically diverse and nutritionally heterogeneous groups of bacteria, including many fermentative bacteria, several sulfur- and sulfate-reducing bacteria $(12,21,33,44,45)$, and some ferric iron reducers $(11,18,22,26)$.

In some water-logged rice field soils, ferrous iron and sulfide, the end products of metabolism of ferric ironreducing bacteria and sulfur- and sulfate-reducing bacteria, respectively, are very toxic for rice $(17 a, 33 a)$. Rice field soils from the Kou Valley in Burkina Faso (West Africa) are acidic and rich in iron. In an attempt to study ferrous iron and sulfide toxicities in these soils, bacterial enrichment cultures were grown with ferric citrate and sulfate as electron acceptors and with various substrates (acetate, propionate, ethanol, lactate) as energy sources. Several lactateutilizing microorganisms (fermentative and sulfate-reducing bacteria) were isolated.

In this paper we describe the isolation and characterization of a lactate-fermenting, facultatively iron-reducing bacterium that was obtained from reduced rice field soils. In view of the morphology and the metabolic properties of the isolate, we propose that this organism is a member of a new species of the genus Anaerovibrio, Anaerovibrio burkinabensis.

\section{MATERIALS AND METHODS}

Origin of strains. Anaerovibrio lipolytica DSM 3074 and Methanospirillum hungatei DSM 864 were obtained from the German Culture Collection. Strain $\mathrm{B}_{4} \mathrm{~B}_{0}^{\mathrm{T}}(\mathrm{T}=$ type strain) was isolated from reduced layers (depth, 10 to $25 \mathrm{~cm}$ ) in four different rice field soils in the Kou Valley of Burkina Faso. The in situ temperature was about $33^{\circ} \mathrm{C}$, and the $\mathrm{pH}$ was

\footnotetext{
* Corresponding author.
}

approximately 7.0. A Methanobacterium sp. strain was obtained from our laboratory collection.

Media and culture conditions. We used the techniques for cultivation of strict anaerobes described by Macy et al. (27) throughout this study. Strains were grown on a basal medium containing (per liter) $0.25 \mathrm{~g}$ of $\mathrm{KH}_{2} \mathrm{PO}_{4}, 0.30 \mathrm{~g}$ of $\mathrm{NH}_{4} \mathrm{Cl}, 1 \mathrm{~g}$ of $\mathrm{NaCl}, 0.50 \mathrm{~g}$ of $\mathrm{KCl}, 0.40 \mathrm{~g}$ of $\mathrm{MgCl}_{2} \cdot 6 \mathrm{H}_{2} \mathrm{O}$, $0.16 \mathrm{~g}$ of $\mathrm{CaCl}_{2} \cdot 2 \mathrm{H}_{2} \mathrm{O}, 0.001 \mathrm{~g}$ of resazurin, and $1 \mathrm{ml}$ of a trace element solution (17). The medium was boiled under a stream of $\mathrm{O}_{2}$-free $\mathrm{N}_{2}$, cooled to room temperature, and dispensed into Hungate tubes or serum bottles by using the Hungate anaerobic technique (16) as modified by Miller and Wollin (29) and Balch and Wolfe (2). After the medium was autoclaved at $110^{\circ} \mathrm{C}$ for $40 \mathrm{~min}, \mathrm{NaHCO}_{3}$ and $\mathrm{Na}_{2} \mathrm{~S}$ were added from heat-sterilized stock solutions to final concentrations of 0.25 and $0.025 \%$, respectively. Just before inoculation, substrates and vitamins $(1 \mathrm{ml}$ per liter of culture medium) were supplied from filter-sterilized stock solutions.

Unless otherwise indicated, all experiments were carried out at $35^{\circ} \mathrm{C}$ and $\mathrm{pH} 7.1$ in a culture medium containing 52 $\mathrm{mM}$ lactate as the sole carbon and energy source. Growth was monitored by measuring optical density at $580 \mathrm{~nm}$ with a Bausch \& Lomb Spectronic 21 spectrophotometer. The $\mathrm{pH}$ range for growth was estimated in a Tris-maleate buffer medium, and the $\mathrm{pH}$ was adjusted with sterile $\mathrm{NaOH}$ solutions. The temperature range for growth was tested at temperatures ranging from 13 to $50^{\circ} \mathrm{C}$. The salt requirement was tested by growing the strain in the presence of 0 to $2 \%$ $\mathrm{NaCl}$ in media. Nutritional tests were carried out simultaneously in four media. Medium 1 was a basal medium that was supplemented with growth factors $(0.1 \%$ yeast extract [Difco Laboratories, Detroit, Mich.] and 0.1\% Biotrypcase [Biomérieux, Craponne, France], $3 \mathrm{mM}$ sodium acetate (as a carbon source), and a substrate at a concentration of 5,10 , or $20 \mathrm{mM}$ (as an energy source). Medium 2 was the same as medium 1 except that the concentrations of the growth factors were decreased to $0.01 \%$. Medium 3 was the same as medium 2 except that the growth factors were omitted. And medium 4 was the same as medium 3 except that acetate was omitted. In addition, 1,3-propanediol utilization was tested in a coculture with a Methanobacterium sp. strain or Methanospirillum hungatei. The vitamin requirement was studied by using the vitamin solutions of Balch et al. (1) and Pfennig 
et al. (31), which were tested separately. The molar growth yield was determined in a 2-liter batch culture containing medium 4 supplemented with $20 \mathrm{mM}$ lactate, $10 \mathrm{mM}$ fructose, or $10 \mathrm{mM}$ glycerol phosphate in the presence of $0.1 \%$ yeast extract. In the determinations of growth yields when glycerol phosphate was used, we corrected for growth without an added energy source. All of the values given below are the means of three determinations.

Iron reduction was tested with lactate $(10 \mathrm{mM})$ and ferric citrate $(10 \mathrm{mM})$. Fe(III) and $\mathrm{Fe}(\mathrm{II})$ were quantified as described by Lovley and Phillips (24). Chemical reduction of $\mathrm{Fe}$ (III) by sulfide, chemical reduction of $\mathrm{Fe}$ (III) by succinate, and chemical reduction of $\mathrm{Fe}$ (III) by any other compound in the medium were quantified in inoculated culture tubes supplemented with $\mathrm{Na}_{2} \mathrm{~S}(0.05 \%)$, succinate $(10 \mathrm{mM})$, and $1 \mathrm{ml}$ of an autoclaved culture of strain $\mathrm{B}_{4} \mathrm{~B}_{0}{ }^{\mathrm{T}}$, respectively. Fumarate $(10 \mathrm{mM})$ was tested as an electron acceptor in the presence of $\mathrm{H}_{2}-\mathrm{CO}_{2}\left(80: 20,1.5 \times 10^{5} \mathrm{~Pa}\right)$. Nitrate $(10$ $\mathrm{mM})$ and sulfate $(10 \mathrm{mM})$ were tested as electrons acceptors in the presence of $\mathrm{H}_{2}-\mathrm{CO}_{2}\left(80: 20,1.5 \times 10^{5} \mathrm{~Pa}\right)$ or $10 \mathrm{mM}$ lactate.

Isolation. Pure cultures were obtained by repeated application of the roll tube method as described by Hungate (16). Strain purity was checked by using a complex medium containing $0.25 \%$ yeast extract, $0.25 \%$ peptone, $0.25 \%$ Biotrypcase, and $0.25 \%$ glucose. The culture was examined microscopically after 3 weeks of incubation.

Cell pigment determination. About $3 \mathrm{~g}$ of cells in $10 \mathrm{ml}$ of $20 \mathrm{mM}$ Tris hydrochloride buffer $(\mathrm{pH} 7.6)$ was sonicated, and the resulting suspension was centrifuged at $30,000 \times g$ for 20 min. The resulting cell extract was separated into the soluble fraction and the particulate fraction by centrifugation at $140,000 \times g$ for $1 \mathrm{~h}$. The particulate fraction was the ultracentrifugation pellet resuspended in the buffer described above. Cytochromes were identified by recording the redox difference spectra of the dithionite-reduced minus air-oxidized portion of each fraction by using a Shimadzu model UV 300 spectrophotometer.

Transmission electron micrographs. Electron micrographs were obtained by using a JEOL model JEM-1200 EX transmission electron microscope and negative staining with $1 \%$ (wt/vol) sodium phosphotungstate. Gram staining was performed by using a standard method and a coloration kit (Sigma Chemical Co., St. Louis, Mo.). Escherichia coli and Micrococcus luteus were used as controls.

Analytical techniques. Volatile fatty acids, organic acids, and alcohols were assayed by high-performance liquid chromatography; the pump was an Analprep 93 pump (Touzart et Matignon, Vitry sur Seine, France), the flow rate was 0.6 $\mathrm{ml} / \mathrm{min}$, the volume of the injection loop was $20 \mu \mathrm{l}$, the column (300 by $6.5 \mathrm{~mm}$ ) was a type ORH-801 column (Interaction Chemicals, Inc., Mountain View, Calif.), the column temperature was $35^{\circ} \mathrm{C}$, the detector was a differential refractometer (Knauer, Berlin, Germany), and the recorder was a Chromatopak C-R3A recorder (Shimadzu, Kyoto, Japan).

Hydrogen and methane were measured by using gas chromatographic methods as described previously (19). Sulfide was measured spectrophotometrically as colloidal $\mathrm{CuS}$ (5).

DNA extraction. DNA was isolated by chromatography on hydroxyapatite (4). The guanine-plus-cytosine $(G+C)$ content of the DNA was determined by using high-performance liquid chromatography; nonmethylated lambda virus DNA was used for calibration (28).

\section{RESULTS}

Isolation. Enumeration by using the most probable number method (three tubes per dilution) with lactate and ferric citrate as the electron acceptors showed that iron reduction occurred at high dilutions $\left(10^{-7}\right.$ to $10^{-8}$ per $\mathrm{g}$ of wet soil). When ferric iron reduction was observed, the highest positive most probable number dilution was chosen for further studies. Cultures were enriched by subjecting them to at least five transfers on a medium containing lactate and ferric citrate. Microscopic observations showed that a motile, nonsporulated vibrio was a major bacterial form in enrichment cultures. To determine whether ferric iron reduction was obligatory or facultative, Fe(III) citrate was omitted from the culture medium; after five subcultures with lactate in the absence of $\mathrm{Fe}$ (III) citrate, the enrichment cultures had the ability to reduce ferric iron, and we observed the same motile, nonsporulated vibrio as the major bacterial form. This showed that ferric iron reduction was facultative; therefore, purifications were performed without $\mathrm{Fe}$ (III) citrate. After 5 days of incubation at $35^{\circ} \mathrm{C}$, circular, lensshaped, ochre to brown colonies appeared. The colonies which we picked reduced ferric iron in liquid medium. Two strains (strains $B_{4} B_{0}{ }^{T}$ and $C_{6} C_{0}$ ) were isolated from four different rice field soils; because these two strains were very similar, strain $\mathbf{B}_{4} \mathbf{B}_{0}{ }^{\mathrm{T}}$ was chosen for further characterization.

Morphology. The cells of strain $\mathrm{B}_{4} \mathbf{B}_{0}{ }^{\mathrm{T}}$ were slightly curved rods $(0.5$ by 1.5 to $3.0 \mu \mathrm{m})$ and were highly motile by means of a single polar flagellum (Fig. 1). In old cultures, the cells were spirilloid and not motile. The cells were gram negative, and spores were not observed.

Physiology. Strain $\mathrm{B}_{4} \mathrm{~B}_{0}{ }^{\mathrm{T}}$ was a strictly anaerobic bacterium. The optimum growth temperature was approximately $35^{\circ} \mathrm{C}$; no growth was observed at temperatures above $43^{\circ} \mathrm{C}$ or below $13^{\circ} \mathrm{C}$ (Fig. 2a). Strain $\mathrm{B}_{4} \mathrm{~B}_{0}^{\mathrm{T}}$ grew optimally at $\mathrm{pH}$ 6.8 and grew at $\mathrm{pH}$ values ranging from 5.3 to 8.5 (Fig. 2b). $\mathrm{No} \mathrm{NaCl}$ requirement was observed. Complete inhibition of growth was observed at an $\mathrm{NaCl}$ concentration of $1.2 \%$ or above (Fig. 2c).

The growth rate determined at $35^{\circ} \mathrm{C}$ and $\mathrm{pH} 6.8$ in a medium containing $1 \mathrm{~g}$ of $\mathrm{NaCl}$ per liter and $20 \mathrm{mM}$ lactate was $0.47 \mathrm{~h}^{-1}$

The molar growth yields determined by using lactate, glycerol phosphate, and fructose were $7.2 \pm 1.5,19.7 \pm 2.0$, and $27.0 \pm 1.8 \mathrm{~g}$ (dry weight) per mol, respectively.

Strain $\mathrm{B}_{4} \mathrm{~B}_{0}^{\mathrm{T}}$ fermented citrate, fumarate, malate, lactate, pyruvate, dihydroxyacetone, fructose, 1,2-propanediol, aspartate, and glutamate. Yeast extract, Casamino Acids, peptone, and Biotrypcase supported slight growth. Glycerol was slightly degraded with no increase in the turbidity of the culture medium. Glycerol 3-phosphate was readily degraded, but very good growth (optical density, 0.9 ) occurred only when $0.1 \%$ yeast extract was provided; in the absence of yeast extract, this substrate was not degraded.

Acetate and propionate in variable amounts and traces of hydrogen were produced from all of the substrates degraded. The following four compounds were detected as major products: (i) acetate from citrate, pyruvate, and glutamate; (ii) propionate from lactate, dihydroxyacetone, fructose, 1,2-propanediol, and glycerol 3-phosphate; (iii) succinate from fumarate, malate, and aspartate; and (iv) 1,3-propanediol from glycerol (Table 1). Small amounts of lactate and succinate were detected when a sugar was degraded (Table 1). Propanol was a main product of 1,2-propanediol fermentation (Table 1). Carbon dioxide was produced, but since this 


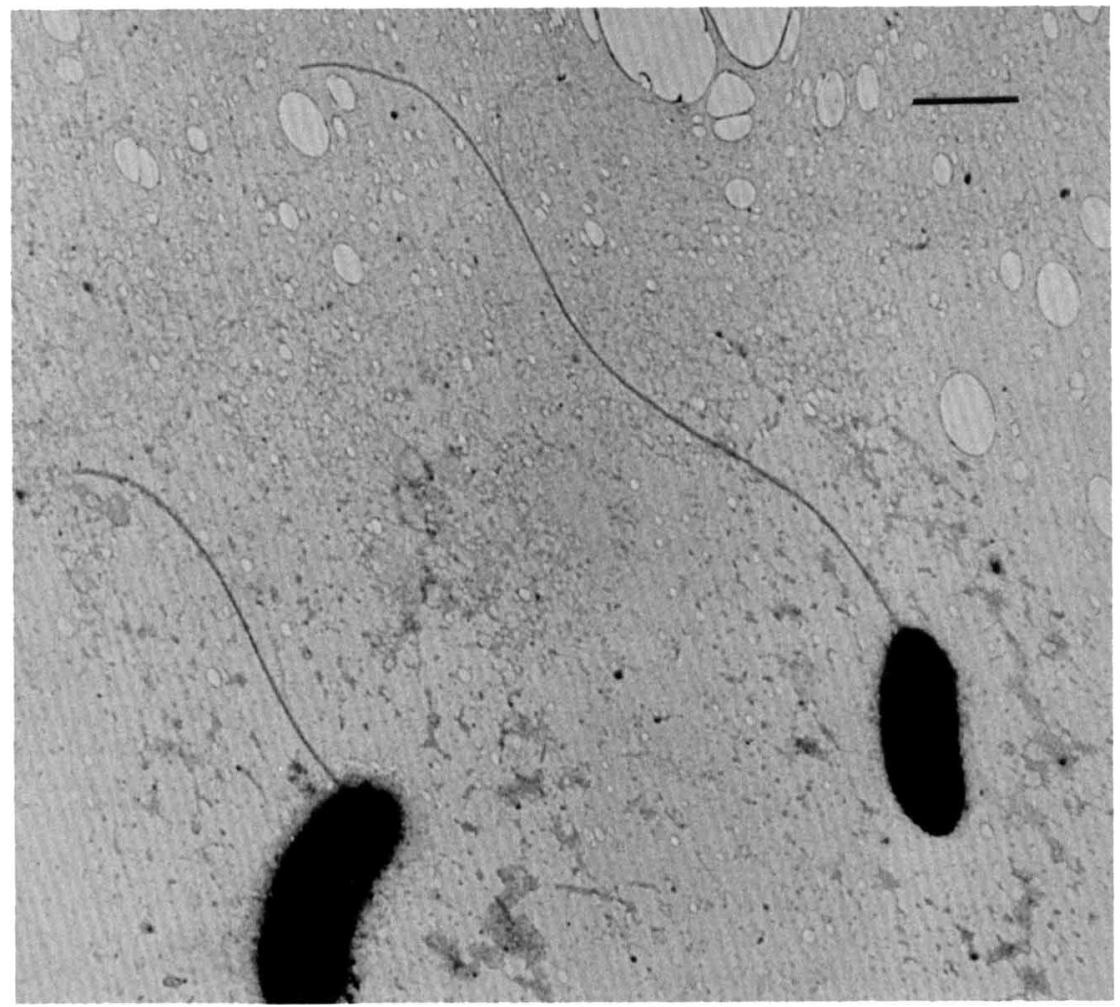

FIG. 1. Electron photomicrograph of strain $B_{4} B_{0}{ }^{T} . B a r=1 \mu \mathrm{m}$.

compound was not quantified after growth of the strain, the levels of total carbon recovery could not be calculated. Malate and amino acid fermentation required acetate as a carbon source (Table 1). Yeast extract was required for growth on glycerol phosphate; yeast extract and Biotrypcase were required for 1,2-propanediol utilization. The substrates that did not support growth included $\mathrm{H}_{2}-\mathrm{CO}_{2}$, methanol, ethanol, propanol, butanol, pentanol, 1,3-propanediol, ethylene glycol, sorbitol, mannitol, dulcitol, adonitol, glyceraldehyde, ribose, xylose, arabinose, glucose, galactose, sorbose, rhamnose, sucrose, lactose, melibiose, raffinose, starch, cellulose, amylose, pectin, formate, acetate, propionate, butyrate, succinate, maleate, choline, alanine, cysteine, lysine, serine, tyrosine, and gelatin.

No growth occurred in a culture medium that lacked vitamins or when the medium was supplemented with the vitamin solution of Pfennig et al. (31). However, substrate fermentation was observed when the same medium was supplemented with the vitamin solution of Balch et al. (1). Growth was observed when both growth factors and the vitamin solution of Pfennig et al. (31) were added to the medium.

In the presence of lactate and ferric citrate, 8 to $10 \mathrm{mM}$ $\mathrm{Fe}$ (II) was produced by strain $\mathrm{B}_{4} \mathrm{~B}_{0}^{\mathrm{T}}$ after 14 to $30 \mathrm{~h}$ of growth; we observed formation of an important quantity of a black precipitate $(\mathrm{FeS})$ in the culture medium, and $10 \mathrm{mM}$ lactate was converted to $5.8 \mathrm{mM}$ acetate and $4.2 \mathrm{mM}$ propionate. During the same time, only 0.2 to $0.4 \mathrm{mM} \mathrm{Fe}(\mathrm{II})$ was produced in culture tubes containing sulfide, succinate, and $1 \mathrm{ml}$ of an autoclaved culture of strain $B_{4} B_{0}{ }^{T}$. When culture tubes were autoclaved, the concentration of $\mathrm{Fe}$ (II) produced was less than $0.5 \mathrm{mM}$. Cell-free filtrates of actively growing cultures of strain $\mathrm{B}_{4} \mathrm{~B}_{0}^{\mathrm{T}}$ did not produce $\mathrm{Fe}(\mathrm{II})$. In the presence of $\mathrm{H}_{2}-\mathrm{CO}_{2}\left(80: 20,1.5 \times 10^{5} \mathrm{~Pa}\right)$, strain $\mathrm{B}_{4} \mathrm{~B}_{0}{ }^{\mathrm{T}}$ converted $10 \mathrm{mM}$ fumarate to $0.1 \mathrm{mM}$ acetate, $2.3 \mathrm{mM}$ propionate, and $7.5 \mathrm{mM}$ succinate; in control culture tubes containing fumarate and $\mathrm{N}_{2}-\mathrm{CO}_{2}\left(80: 20,1.5 \times 10^{5} \mathrm{~Pa}\right)$, the concentrations of acetate, propionate, and succinate were $4.8,2.4$, and $5.1 \mathrm{mM}$, respectively.

In the presence of $\mathrm{H}_{2}-\mathrm{CO}_{2}\left(80: 20,1.5 \times 10^{5} \mathrm{~Pa}\right)$, or lactate and nitrate, nitrite and ammonia were not produced. In a medium containing sulfate, $\mathrm{H}_{2}-\mathrm{CO}_{2}\left(80: 20,1.5 \times 10^{5} \mathrm{~Pa}\right)$, or lactate, sulfide was not detected. The stoichiometry of lactate fermentation $(3.3 \mathrm{mM}$ acetate, $6.6 \mathrm{mM}$ propionate, and $0.02 \mathrm{mM}$ succinate) in the presence of nitrate or sulfate was the same as that in control tubes without these compounds.

No methane production was observed when strain $\mathbf{B}_{4} \mathbf{B}_{0}{ }^{\mathrm{T}}$ was cultured with Methanobacterium sp. or Methanospirillum hungatei in medium containing 1,3-propanediol.

Pigments. In the soluble and the particulate fractions, the reduced spectra contained the characteristic absorption bands of type $b$ cytochromes with maxima at 423,525 , and $555 \mathrm{~nm}$. The oxidized extract had an absorption maximum at $408 \mathrm{~nm}$. The cytochrome was not reduced by sodium ascorbate, which indicated that it had a low midpoint redox potential. Fumarate reoxidized the cytochrome (data not shown).

DNA base composition. The $\mathrm{G}+\mathrm{C}$ content of the DNA was $44.1 \pm 0.1 \mathrm{~mol} \%$ (mean of three determinations).

\section{DISCUSSION}

Physiology. Strain $\mathrm{B}_{4} \mathrm{~B}_{0}{ }^{\mathrm{T}}$ is a strictly anaerobic vibrio that uses lactate and a broad range of substrates, including 

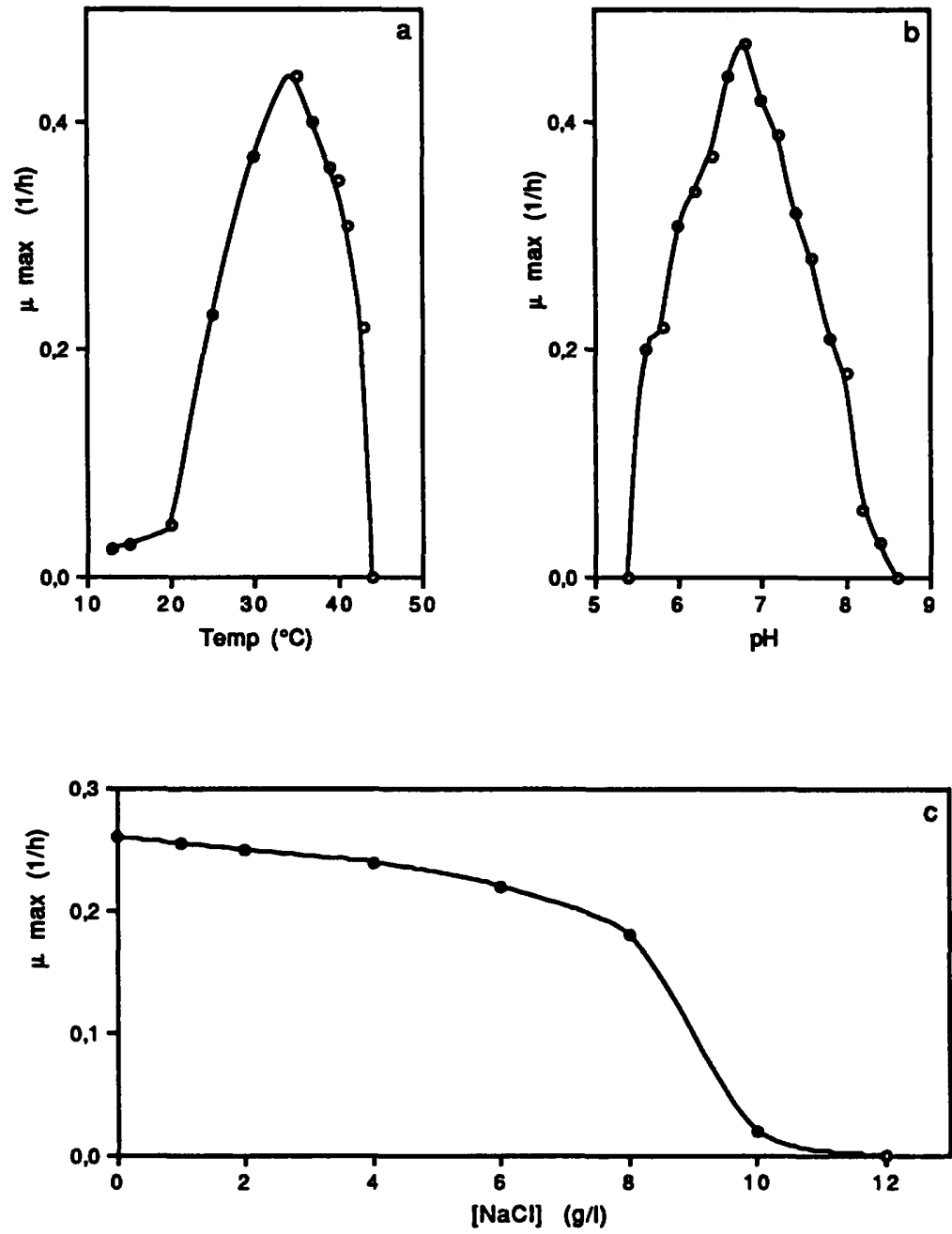

FIG. 2. Effects of temperature (a), $\mathrm{pH}(\mathrm{b})$, and $\mathrm{NaCl}$ concentration (c) on the growth rate of strain $\mathbf{B}_{4} \mathrm{~B}_{0}{ }^{\mathrm{T}}$.

organic acids, sugars, 1,2-propanediol, and some amino acids, as energy sources.

The fermentation end products are acetate and propionate in variable amounts, as well as traces of hydrogen. Succinate (from the tri- and dicarboxylic acids tested) and propanol (from 1,2-propanediol) are additional main products. We detected traces of lactate and succinate from sugar metabolism.

TABLE 1. End products of substrate fermentations by strain $\mathbf{B}_{4} \mathbf{B}_{0}{ }^{\mathrm{T}}$

\begin{tabular}{|c|c|c|c|c|c|c|}
\hline \multirow{2}{*}{ Substrate } & \multicolumn{6}{|c|}{ Concn $(\mathrm{mM})$ of the following fermentation products ${ }^{a}$ : } \\
\hline & Acetate & Propionate & Lactate & Succinate & Propanol & Hydrogen \\
\hline Citrate $(20 \mathrm{mM})$ & 34.4 & & & 6.0 & & $0.1-0.4$ \\
\hline Fumarate (20 mM) & 9.4 & 4.6 & & 10.1 & & $0.1-0.4$ \\
\hline Malate $(20 \mathrm{mM})^{b}$ & 10.2 & 1.6 & & 12.8 & & $0.1-0.4$ \\
\hline Lactate $(20 \mathrm{mM})$ & 6.7 & 13.3 & & & & $0.1-0.4$ \\
\hline Pyruvate $(20 \mathrm{mM})$ & 14.8 & 5.2 & & & & $0.1-0.4$ \\
\hline Dihydroxyacetone (10 $\mathrm{mM})$ & 4.5 & 5.8 & $<0.05$ & $<0.04$ & & $0.1-0.4$ \\
\hline Fructose $(10 \mathrm{mM})$ & 8.8 & 11.2 & $<0.05$ & $<0.08$ & & $0.1-0.4$ \\
\hline Glycerol $(10 \mathrm{mM})^{c}$ & $<0.01$ & 1.4 & & & & $0.1-0.4$ \\
\hline 1,2-Propanediol $(20 \mathrm{mM})^{b}$ & 0.4 & 11.4 & & & 7.6 & $0.1-0.4$ \\
\hline Aspartate $(20 \mathrm{mM})^{b}$ & 6.2 & 4.2 & & 9.5 & & $0.1-0.4$ \\
\hline Glutamate $(20 \mathrm{mM})^{b}$ & 32.9 & 7.3 & & & & $0.1-0.4$ \\
\hline
\end{tabular}

a Data were corrected for control values.

${ }^{b}$ Acetate was required for substrate utilization.

c Glycerol was degraded to 1,3-propanediol $(4.5 \mathrm{mM})$, propionate $(1.4 \mathrm{mM})$, and traces of acetate and hydrogen, but no growth was observed. In the presence of $0.1 \%$ yeast extract, glycerol phosphate $(14 \mathrm{mM})$ was readily degraded with good growth to propionate $(12.0 \mathrm{mM})$ and acetate (1.5 mM). 
The occurrence of succinate as an end product of metabolism suggests that propionate is formed via a dicarboxylic acid pathway (35). Degradation of reduced compounds, such as 1,2-propanediol, 1,3-propanediol, and glycerol, by strictly anaerobic bacteria requires an external electron acceptor $(8$, $30,36)$. This suggests that the yeast extract and biotrypcase required for 1,2-propanediol fermentation act as electron acceptors (36). The members of several groups of bacteria produce 1,3-propanediol and acids from glycerol fermentation $(10,13,38,40-42)$. The mechanism of 1,3-propanediol formation from glycerol is conversion of the substrate (via dehydratation) to 3-hydroxypropionaldehyde, which is then reduced to 1,3-propanediol $(9,10,13,38,40-42)$. Fermentation data have suggested that the use of glycerol as an indirect $\mathrm{H}$ acceptor (3-hydroxypropionaldehyde is the direct $\mathrm{H}$ acceptor) through its conversion to 1,3-propanediol does not generate ATP and leads to an irretrievable loss of substrate for generation of ATP and cell material $(13,42)$. The outstanding property of Anaerovibrio species is anaerobic degradation of glycerol to mainly propionate $(14,34,35$, $37)$. Glycerol is thought to be fermented via glycerol kinase, as reported previously for propionic acid bacteria $(7,37)$. Our results for glycerol degradation can be interpreted as dismutation of glycerol. The glycerol-3-phosphate fermentation pattern (exclusive of conversion to propionate) is similar to the fermentation patterns of propionic acid bacteria, such as Anaerovibrio and Propionibacterium species (6, 7, 35, 37). The inability to use glycerol but not glycerol 3-phosphate and dihydroxyacetone suggests that there may be two pathways for anaerobic glycerol degradation, one pathway which involves glycerol dehydratase and a second pathway that is similar to the pathways in propionic acid bacteria (35, 37). Glycerol dismutation to 1,3-propanediol instead of fermentation to propionate may result from (i) the absence of glycerol kinase or the inability of glycerol kinase to express its potential, or (ii) a greater affinity of glycerol dehydratase than glycerol kinase for the substrate.

The absence of 1,3-propanediol degradation may be due to a lack of enzymatic equipment that is responsible of the degradation of this substrate rather than excess electron release.

Strain $\mathbf{B}_{\mathbf{4}} \mathbf{B}_{0}{ }^{\mathbf{T}}$ used ferric iron as an electron acceptor. Utilization of $\mathrm{Fe}$ (III) as a minor electron sink is common in a wide variety of fermentative bacteria (22). We could not determine whether using $\mathrm{Fe}$ (III) as an electron sink provided a slightly greater energy yield than fermentation alone.

About $50 \%$ of the fumarate provided as substrate was converted to succinate (the end product of fumarate reduction) by strain $\mathrm{B}_{4} \mathrm{~B}_{0}^{\mathrm{T}}$ (Table 1). This level increased to $75 \%$ and the amount of acetate produced drastically decreased when the isolate was grown with fumarate in the presence of hydrogen. All of these data suggest that fumarate is used as an electron acceptor. The reduction of fumarate by the cytochromes of strain $\mathrm{B}_{4} \mathrm{~B}_{0}^{\mathrm{T}}$ is consistent with the use of fumarate as an electron acceptor. Cytochrome $b$ has been shown to be involved in anaerobic electron transport to fumarate in Selenomonas ruminantium, A. lipolytica, and Veillonella alcalescens (6). The reoxidation of the cytochrome $b$ of strain $B_{4} B_{0}{ }^{t}$ by fumarate suggests the presence of a cytochrome $b$-linked electron transport system to fumarate.

Nitrate and sulfate were not used as electron acceptors.

Ecology. Under anaerobic conditions, microbially reducible iron is often the most abundant potential electron acceptor for bacterial metabolism $(32,43)$. In anaerobiosis, ferric iron can be reduced by some fermenting bacteria (11,
$22,24)$; obligatory ferric iron dissimilatory reduction coupled with substrate oxidation can be carried out by facultatively or strictly anaerobic bacteria $(23,25,26)$.

Because of its facultative ability to reduce ferric iron, strain $B_{4} B_{0}^{T}$ could contribute to ferrous iron toxicity in rice fields.

The optimal temperature, optimal $\mathrm{pH}$, and optimal $\mathrm{NaCl}$ concentration determined by laboratory studies were very similar to the in situ conditions observed in the rice field soils of the Kou Valley $\left(33^{\circ} \mathrm{C}, \mathrm{pH} 7.0\right.$, and traces of $\mathrm{NaCl}$ ), showing that strain $B_{4} B_{0}{ }^{T}$ is well adapted to its site of isolation.

Taxonomy. As a gram-negative, strictly anaerobic, nonspore-forming, chemoorganotrophic organism that forms acetate and propionate, strain $B_{4} B_{0}{ }^{T}$ belongs to the family Bacteroidaceae and should be compared with the genera Anaerovibrio (34, 37), Pectinatus (20), Propionispira (39), and Selenomonas (3). All of these genera ferment numerous substrates, including sugars and organic acids, to mainly acetate and propionate $(3,20,34,37,39)$. Identification of strain $\mathrm{B}_{4} \mathrm{~B}_{0}^{\mathrm{T}}$ as a member of the genus Pectinatus, Propionispira, or Selenomonas is not possible because of the differences observed in the type of flagellation and the inability of strain $B_{4} B_{0}^{T}$ to ferment arabinose, galactose, glucose, and mannitol (Table 2). In contrast to species belonging to the genera Pectinatus and Propionispira, strain $\mathrm{B}_{4} \mathrm{~B}_{0}{ }^{\mathrm{T}}$ does not ferment cellobiose (Table 2). Unlike Selenomonas spp., strain $\mathrm{B}_{4} \mathrm{~B}_{0}^{\mathrm{T}}$ ferments fructose and does not use lactose and mannose (Table 2). The other sugars that are not used by strain $\mathrm{B}_{4} \mathrm{~B}_{0}^{\mathrm{T}}$ but are readily fermented by species belonging to the genera Pectinatus, Propionispira, and Selenomonas are listed in Table 2 . When we considered (i) morphology and the type of flagellation, (ii) the cytochrome content, (iii) the ability to ferment dihydroxyacetone, fructose, lactate, and glycerol phosphate, and (iv) the occurrence of the same end products from these fermentations, strain $B_{4} B_{0}{ }^{T}$ appeared to be more closely related to the genus Anaerovibrio. However, in contrast to the previously described Anaerovibrio spp., which readily ferment glycerol to mainly propionate $(6,34,37)$, strain $\mathbf{B}_{4} \mathbf{B}_{0}{ }^{\mathbf{T}}$ degrades glycerol without growth to 1,3-propanediol (the main product), propionate, and traces of acetate and hydrogen; also, there is a difference of 10 to $13 \mathrm{~mol} \%$ between the $\mathrm{G}+\mathrm{C}$ contents of strain $\mathrm{B}_{4} \mathrm{~B}_{0}{ }^{\mathrm{T}}$ DNA and DNAs of species belonging to the genus Anaerovibrio (Table 2). Despite these differences, we suggest that strain $\mathrm{B}_{4} \mathrm{~B}_{0}{ }^{\mathrm{T}}$ should be assigned to the genus Anaerovibrio since wide divergences in DNA G $+C$ contents have been described previously (for example, within the genera Desulfovibrio [42 to $68 \mathrm{~mol} \%$ ] and Clostridium [22 to $55 \mathrm{~mol} \%$ ]). This assignment, which is based on morphological and physiological characteristics, is not as indisputable as an assignment based on DNA-DNA or DNA-RNA hybridization data, but currently seems to be the most acceptable alternative. If this assignment is confirmed by phylogenetic experiments, emendation of the description of the genus Anaerovibrio concerning degradation of glycerol will be necessary.

A. lipolytica $(14,15)$ and Anaerovibrio glycerini (37) are the only two previously described species of the genus Anaerovibrio. While $A$. glycerini is highly specialized to ferment glycerol and its derivatives (37), A. lipolytica also ferments in addition to these substrates lactate, dihydroxyacetone (this study), fructose, and ribose $(14,15)$. Unlike the other two species described previously, strain $B_{4} B_{0}{ }^{T}$ ferments citrate, fumarate, malate, pyruvate, and 1,2-propanediol (Table 3). Strain $B_{4} B_{0}{ }^{T}$ also has a higher DNA $G+C$ 
TABLE 2. Comparison of strain $\mathrm{B}_{4} \mathrm{~B}_{0}{ }^{\mathrm{T}}$ with some acetate- and propionate-producing genera of the family Bacteroidacea $e^{a}$

\begin{tabular}{|c|c|c|c|c|c|}
\hline Characteristic & Strain $\mathrm{B}_{4} \mathrm{~B}_{0}{ }^{\mathrm{T}}$ & Anaerovibrio & Pectinatus & Propionispira & Selenomonas \\
\hline \multicolumn{6}{|l|}{ Morphology } \\
\hline Cell shape & Curved rods & Curved rods & Curved rods & Curved rods & Curved rods \\
\hline Cell width $(\mu \mathrm{m})$ & 0.5 & 0.5 & $0.7-0.8$ & 1 & $0.9-1.1$ \\
\hline Cell length $(\mu \mathrm{m})$ & $1.5-3$ & $1.2-3.6$ to 10 & $2-32$ & 7 & $3-6$ \\
\hline Multiple flagella & $(-)$ & $(-)$ & $(+)$ & $(+)$ & $(+)$ \\
\hline Flagellum location & Polar & Polar & Lateral & Peritrichous & Lateral tuft \\
\hline $\mathrm{G}+\mathrm{C}$ content $(\mathrm{mol} \%)$ & 44.1 & $31-34$ & 40 & 37 & $54-61$ \\
\hline \multicolumn{6}{|l|}{ Fermentation of: } \\
\hline Arabinose & - & - & + & + & + \\
\hline Cellobiose & - & - & + & + & $\mathbf{v}$ \\
\hline Fructose & + & + & + & NR & - \\
\hline Galactose & - & - & + & + & + \\
\hline Glucose & - & - & + & + & + \\
\hline Lactose & - & - & - & + & + \\
\hline Maltose & - & - & + & - & + \\
\hline Mannose & - & - & + & + & NR \\
\hline Raffinose & - & - & - & + & $\mathbf{v}$ \\
\hline Rhamnose & - & - & + & - & NR \\
\hline Ribose & - & + & + & NR & NR \\
\hline Sucrose & - & - & - & + & + \\
\hline Xylose & - & - & - & + & + \\
\hline Adonitol & - & - & + & NR & - \\
\hline Glycerol & $\mathbf{w}$ & + & + & + & $\mathbf{v}$ \\
\hline Mannitol & - & - & + & + & + \\
\hline Lactate & + & + & + & + & $\mathbf{v}$ \\
\hline Esculin & - & - & - & - & + \\
\hline
\end{tabular}

${ }^{a}$ See text for references. The characteristics in the table are common to the currently described species or strain(s) of each genus. (+), two or more flagella; $(-)$, one flagellum; lateral tuft, lateral tuft in the center of the concave side of the cell; + , fermented; - , not fermented; w, degradation without growth; $v$, variable (fermented by some species or subspecies); NR, not reported.

content $(44.1 \pm 0.1 \mathrm{~mol} \%)$ than $A$. glycerini $(34.3 \pm 1.0$ mol\%) and $A$. lipolytica $(31.5 \pm 1.2 \mathrm{~mol} \%)$. Therefore, strain $\mathrm{B}_{4} \mathrm{~B}_{0}^{\mathrm{T}}$ is a new type of anaerobic bacterium that cannot be placed in either of the previously described species. We propose that strain $\mathrm{B}_{4} \mathrm{~B}_{0}$ is the type strain of a new species of the genus Anaerovibrio, Anaerovibrio burkinabensis. The

TABLE 3. Differentiation of strain $\mathrm{B}_{4} \mathrm{~B}_{0}{ }^{\mathrm{T}}$ from other species of the genus Anaerovibrio ${ }^{a}$

\begin{tabular}{|c|c|c|c|}
\hline Characteristic & A. glycerini & A. lipolytica & Strain $\mathbf{B}_{\mathbf{4}} \mathbf{B}_{0}{ }^{\mathrm{T}}$ \\
\hline \multicolumn{4}{|l|}{ Fermentation of: } \\
\hline Citrate & $-b$ & - & + \\
\hline Fumarate & - & - & + \\
\hline Malate & - & - & + \\
\hline Lactate & - & + & + \\
\hline Pyruvate & - & - & + \\
\hline Dihydroxyacetone & - & + & + \\
\hline Fructose & - & + & + \\
\hline Ribose & - & + & - \\
\hline 1,2-Propanediol & - & - & + \\
\hline Glycerol & + & + & $\mathbf{w}$ \\
\hline Diolein & + & + & ND \\
\hline Aspartate & - & - & + \\
\hline Glutamate & - & - & + \\
\hline Yeast extract & - & + & + \\
\hline Temp range $\left({ }^{\circ} \mathrm{C}\right)$ & $10-42$ & $35-45$ & $13-43$ \\
\hline Optimum temp $\left({ }^{\circ} \mathrm{C}\right)$ & 37 & 38 & 35 \\
\hline $\mathrm{pH}$ range & $5.0-8.5$ & $5.7-7.0$ & $5.3-8.4$ \\
\hline Optimum pH & $6.5-7.5$ & 6.3 & 6.8 \\
\hline Cytochrome(s) & $b$ & $a, b$ & $b$ \\
\hline $\mathrm{G}+\mathrm{C}$ content $(\mathrm{mol} \%)$ & 34.3 & 31.5 & 44.1 \\
\hline
\end{tabular}

\footnotetext{
a See text for references.
}

${ }^{b}+$, substrate fermented; - substrate not fermented; w, substrate degraded without growth; ND, not determined. description of this isolate below extends the range of substrates which are fermented by Anaerovibrio species.

Description of Anaerovibrio burkinabensis sp. nov. Anaerovibrio burkinabensis (bur.ki.na.ben'sis. N. L. adj. burkinabensis, from Burkinabe, inhabitants of Burkina Faso, West Africa). Curved, spiral-shaped cells that are 0.5 by 1.5 to $3.0 \mu \mathrm{m}$. Motile in young cultures. Gram negative and non-spore forming.

Strictly anaerobic chemoorganotroph. Citrate, fumarate, malate, lactate, pyruvate, 1,2-propanediol, dihydroxyacetone, fructose, aspartate, glutamate, glycerol phosphate, yeast extract, Biotrypcase, and Casamino acids are used as energy sources. Acetate is required for fermentation of malate, 1,2-propanediol, and amino acids, yeast extract is required for glycerol phosphate degradation, and yeast extract and Biotrypcase are required for 1,2-propanediol utilization. Succinate is the main product of malate, fumarate, or aspartate fermentation, while acetate and propionate are the main products resulting from fermentations of other substrates. Propanol is produced from 1,2-propanediol. Glycerol is mainly degraded to 1,3-propanediol. Traces of succinate, lactate (in sugar fermentations), and hydrogen are also produced.

Vitamins are required for growth. $\mathrm{NaCl}$ is not required. Ferric iron is reduced. Sulfate and nitrate are not reduced. Cytochrome $b$ is present. Substrates that do not support growth include $\mathrm{H}_{2}-\mathrm{CO}_{2}$, methanol, ethanol, propanol, butanol, pentanol, 1,3-propanediol, ethylene glycol, sorbitol, mannitol, dulcitol, adonitol, glyceraldehyde, ribose, xylose, arabinose, glucose, galactose, sorbose, rhamnose, sucrose, lactose, melibiose, raffinose, starch, cellulose, amylose, pectin, formate, acetate, propionate, butyrate, succinate, maleate, choline, alanine, cysteine, lysine, serine, tyrosine, and gelatin. 
The $\mathrm{pH}$ range for growth is 5.3 to 8.4 ; the optimum $\mathrm{pH}$ is around 6.8. The temperature range for growth is 13 to $43^{\circ} \mathrm{C}$; the optimum temperature is around $35^{\circ} \mathrm{C}$. The $\mathrm{NaCl}$ range for growth is 0 to $1.2 \%$; optimum growth occurs at an $\mathrm{NaCl}$ concentration of $0 \%$.

The DNA base ratio is $44.1 \pm 0.1 \mathrm{~mol} \% \mathrm{G}+\mathrm{C}$.

The habitat is anoxic sediments of rice field soils in the Kou Valley, Bama, Burkina Faso, West Africa.

The type strain, strain $\mathbf{B}_{4} \mathbf{B}_{0}$ (= DSM 6283), has been deposited in the Deutsche Sammlung von Mikroorganismen GmbH, Braunschweig, Germany.

\section{ACKNOWLEDGMENTS}

We are indebted to B. Ollivier and V. Jacq for helpful discussions and for reviewing the manuscript, to $\mathrm{N}$. Cuzin for supplying Methanobacterium sp., to C. E. Hatchikian for determining the cytochromes, to K. D. Jahnke for determinating the DNA base ratio, to C. Allasia and J. L. Cayol for providing electron microscopy facilities, and to J. Blanc and P. Roger for revising the English.

\section{REFERENCES}

1. Balch, W. E., G. E. Fox, L. J. Magnum, and R. S. Wolfe. 1979. Methanogens: reevaluation of a unique biological group. Microbiol. Rev. 43:260-296.

2. Balch, W. E., and R. S. Wolfe. 1976. New approach to the cultivation of methanogenic bacteria: 2-mercaptoethanesulfonic acid (HS-CoM)-dependent growth of Methanobacterium ruminantium in a pressurized atmosphere. Appl. Environ. Microbiol. 32:781-791.

3. Bryant, M. P. 1984. Genus IX. Selenomonas, p. 650-653. In N. R. Krieg and J. G. Holt (ed.), Bergey's manual of systematic bacteriology, vol. 1. The Williams \& Wilkins Co., Baltimore.

4. Cashion, P., M. A. Holder-Franklin, J. McCully, and M. Franklin. 1977. A rapid method for the base ratio determination of bacterial DNA. Anal. Biochem. 81:461-466.

5. Cord-Ruwisch, R. 1985. A quick method for the determination of dissolved and precipitated sulfides in cultures of sulfatereducing bacteria. J. Microbiol. Methods 4:33-36.

6. De Vries, W., W. M. C. van Wijck-Kapteyn, and S. K. H. Oosterhuis. 1974. The presence and function of cytochromes in Selenomonas ruminantium, Anaerovibrio lipolytica and Veillonella alcalescens. J. Gen. Microbiol. 81:69-78.

7. De Vries, W., W. M. C. van Wijck-Kapteyn, and A. H. Stoutahamer. 1973. Generation of ATP during cytochrome-linked anaerobic electron transport in propionic bacteria. J. Gen. Microbiol. 76:31-41.

8. Dubourguier, H. C., E. Samain, G. Prensier, and G. Albagnac. 1986. Characterization of two strains of Pelobacter carbinolicus isolated from anaerobic digesters. Arch. Microbiol. 145:248253.

9. Forage, R. G., and M. A. Foster. 1982. Glycerol fermentation in Klebsiella pneumoniae: functions of the coenzyme $\mathrm{B}_{12}$-dependent glycerol and diol dehydratases. J. Bacteriol. 149:413-419.

10. Forsberg, C. W. 1987. Production of 1,3-propanediol from glycerol by Clostridium acetobutylicum and other Clostridium species. Appl. Environ. Microbiol. 53:639-643.

11. Ghiorse, W. C. 1988. Microbial reduction of manganese and iron, p. 305-331. In A. J. B. Zehnder (ed.), Biology of anaerobic microorganisms. John Wiley, New York.

12. Hansen, T. A. 1988. Physiology of sulfate-reducing bacteria. Microbiol. Sci. 5:81-84.

13. Heyndrickx, M., P. De Vos, M. Vancanneyt, and J. De Ley. 1991. The fermentation of glycerol by Clostridium butyricum LMG $1212 \mathrm{t}_{2}$ and $1213 \mathrm{t}_{1}$ and $C$. pasteurianum LMG 3285. Appl. Microbiol. Biotechnol. 34:637-642.

14. Hobson, P. N., and S. O. Mann. 1961. The isolation of glycerolfermenting and lipolytic bacteria from the rumen of sheep. J. Gen. Microbiol. 25:227-240.

15. Hungate, R. E. 1966. The rumen and its microbes. Academic Press, New York.

16. Hungate, R. E. 1969. A roll tube method for the cultivation of strict anaerobes. Methods Microbiol. 3B:117-132.

17. Imhoff-Stuckle, D., and N. Pfennig. 1983. Isolation and characterization of nicotinic acid-degrading sulfate-reducing bacterium, Desulfococcus niacini sp. nov. Arch. Microbiol. 136:194 198.

17a.Jacq, V. A. 1989. Ph.D. thesis. University of Provence, Marseille, France.

18. Jones, J. G., W. Davison, and S. Gardener. 1984. Iron reduction by bacteria: range of organisms involved and metals reduced. FEMS Microbiol. Lett. 21:133-136.

19. Labat, M., and J. L. Garcia. 1986. Study of the development of methanogenic microflora during anaerobic digestion of sugar beet pulp. Appl. Microbiol. Biotechnol. 25:163-168.

20. Lee, S. Y. 1984. Genus XI. Pectinanus, p. 657-658. In N. R. Krieg and J. G. Holt (ed.), Bergey's manual of systematic bacteriology, vol. 1. The Williams \& Wilkins Co., Baltimore.

21. LeGall, J., and G. Fauque. 1988. Dissimilatory reduction of sulfur compounds, p. 587-639. In A. J. B. Zehnder (ed.), Biology of anaerobic microorganisms. John Wiley, New York.

22. Lovley, D. R. 1987. Organic matter mineralization with the reduction of ferric iron: a review. Geomicrobiol. J. 5:375-399.

23. Lovley, D. R., and D. J. Lonergan. 1990. Anaerobic oxidation of toluene, phenol, and $p$-cresol by the dissimilatory iron-reducing organism, GS-15. Appl. Environ. Microbiol. 56:1858-1864.

24. Lovley, D. R., and E. J. P. Phillips. 1986. Organic matter mineralization with reduction of ferric iron in anaerobic sediments. Appl. Environ. Microbiol. 51:683-689.

25. Lovley, D. R., and E. J. P. Phillips. 1988. Novel mode of microbial energy metabolism: organic carbon oxidation coupled to dissimilatory reduction of iron or manganese. Appl. Environ. Microbiol. 54:1472-1480.

26. Lovley, D. R., E. J. P. Phillips, and D. J. Lonergan. 1989. Hydrogen and formate oxidation coupled to dissimilatory reduction of iron or manganese by Alteromonas putrefaciens. Appl. Environ. Microbiol. 55:700-706.

27. Macy, J. M., J. E. Snellen, and R. E. Hungate. 1972. Use of syringe methods for anaerobiosis. Am. J. Clin. Nutr. 25:13181323.

28. Meshbah, M., U. Premachandran, and W. Withman. 1989. Precise measurement of the $\mathrm{G}+\mathrm{C}$ content of deoxyribonucleic acid by high-performance liquid chromatography. Int. J. Syst. Bacteriol. 39:159-167.

29. Miller, T. L., and M. J. Wolin. 1974. A serum bottle modification of the Hungate technique for cultivating obligate anaerobes. Appl. Microbiol. 27:985-987.

30. Oppenberg, B., and B. Schink. 1989. Anaerobic degradation of 1,3-propanediol by sulfate-reducing bacteria. Antonie van Leeuwenhoek 57:205-213.

31. Pfennig, N., F. Widdel, and H. G. Trüper. 1981. The dissimilatory sulfate-reducing bacteria, p. 926-940. In M. P. Starr, H. Stolp, H. G. Trüper, A. Balows, and H. G. Schlegel (ed.), The prokaryotes, vol. 1. Springer-Verlag KG, Berlin.

32. Ponnamperuma, F. N. 1972. The chemistry of submerged soils. Adv. Agron. 24:29-96.

33. Postgate, J. R. 1984. The sulphate-reducing bacteria. Cambridge University Press, Cambridge.

33a.Prade, K. 1987. Ph.D. thesis. University of Hohenheim, Stuttgart-Hohenheim, Germany.

34. Prins, R. A. 1984. Genus X. Anaerovibrio, p. 653-655. In N. R. Krieg and J. G. Holt (ed.), Bergey's manual of systematic bacteriology, vol. 1. The Williams \& Wilkins Co., Baltimore.

35. Prins, R. A., A. Lankhorst, P. van der Meer, and C. J. van Nevel. 1975. Some characteristics of Anaerovibrio lipolytica, a rumen lipolytic organism. Antonie van Leeuwenhoek J. Microbiol. Serol. 41:1-11.

36. Qatibi, A. I., J. L. Cayol, and J. L. Garcia. 1991. Glycerol and propanediols degradation by Desulfovibrio alcoholovorans in pure culture in presence of sulfate, or in syntrophic association with Methanospirillum hungatei. FEMS Microbiol. Ecol. 85: 233-240.

37. Schauder, R., and B. Schink. 1989. Anaerovibrio glycerini sp., an anaerobic bacterium fermenting glycerol to propionate, cell matter, and hydrogen. Arch. Microbiol. 152:473-478. 
38. Schink, B., and M. Stieb. 1983. Fermentative degradation of polyethylene glycol by a new, strictly anaerobic, gram-negative, non-sporeforming bacterium, Pelobacter venetianus sp. nov. Appl. Environ. Microbiol. 45:1905-1913.

39. Schink, B., T. E. Thompson, and J. G. Zeikus. 1982. Characterization of Propionispira arboris gen. nov. sp. nov., a nitrogenfixing anaerobe common to wetwoods of living trees. J. Gen. Microbiol. 128:2771-2780.

40. Schütz, H., and F. Rader. 1984. Anaerobic reduction of glycerol to propanediol-1,3 by Lactobacillus brevis and Lactobacillus buchneri. Syst. Appl. Microbiol. 5:169-178.

41. Stieb, M., and B. Schink. 1984. A new 3-hydroxybutyratefermenting anaerobe, Ilyobacter polytropus, gen. nov., sp. nov., possessing various fermentation pathways. Arch. Microbiol. 140:139-146.

42. Streekstra, H., M. J. Teixeira de Mattos, O. Neijssel, and D. W.
Tempest. 1987. Overflow metabolism during anaerobic growth of Klebsiella aerogenes NCTC 418 on glycerol and dihydroxyacetone in chemostat culture. Arch. Microbiol. 147:268-275.

43. Van Breeman, N. 1988. Effects of seasonal redox processes involving iron on the chemistry of periodically reduced soils, $\mathrm{p}$. 797-809. In J. W. Stucki, B. A. Goodman, and U. Schwertmann (ed.), Iron in soils and clay minerals. D. Reidel Publishing Co., Boston.

44. Widdel, F. 1988. Microbiology and ecology of sulfate- and sulfur-reducing bacteria, p. 469-585. In A. J. B. Zehnder (ed.), Biology of anaerobic microorganisms. John Wiley, New York.

45. Widdel, F., and N. Pfennig. 1984. Dissimilatory sulfate- or sulfur-reducing bacteria, p. 663-679. In N. R. Krieg and J. G. Holt (ed.), Bergey's manual of systematic bacteriology, vol. 1. The Williams \& Wilkins Co., Baltimore. 